\title{
BEM-ESTAR, QUALIDADE DE VIDA E REGULAÇÃO EMOCIONAL: a prática do yoga como terapia complementar
}

\author{
Luana Felício da Silva Dariva ${ }^{1}$ \\ Dionéia Luciane Mendes ${ }^{2}$
}

Resumo: Tendo em vista o aumento dos transtornos mentais na população em geral, bem como a implementação da prática de yoga na PNPIC, o presente estudo teve como objetivos investigar se a prática do yoga influencia na qualidade de vida, no bem-estar e na regulação emocional do indivíduo, verificando sua contribuição para a saúde mental de praticantes, a importância psicossocial na vida do indivíduo, bem como, a influência da prática de yoga na promoção de saúde em pacientes de um CAPS-II do Litoral Norte do Rio Grande do Sul. Pesquisa qualitativa de caráter exploratório. Os instrumentos utilizados foram um questionário sociodemográfico, entrevista semiestruturada e Questionário de Saúde Geral de Goldberg QSG 28. Participaram da pesquisa seis indivíduos incluídos na oficina de yoga de um Centro de Atenção Psicossocial - CAPS-II do Litoral Norte do Rio Grande do Sul. A análise dos dados da entrevista foi realizada através do método de Bardin, e o QSG - 28 conforme protocolo de correção. Os resultados obtidos mostraram que os indivíduos praticantes do yoga apresentaram benefícios a nível emocional, físico, psicológico e social, além de benefícios na regulação emocional com a prática do yoga.

Palavras-chave: Yoga. Qualidade de Vida. Bem-Estar. Regulação Emocional.

WELL-BEING, QUALITY OF LIFE AND EMOTIONAL REGULATION: The practice of yoga as complementary therapy

Abstract: Given the increase of mental disorders in general population, and the implementation of yoga practice in PNPIC as countermeasure, the present study aims to

\footnotetext{
${ }^{1}$ Acadêmica do Curso de Bacharelado em Psicologia da UNICNEC.

${ }^{2}$ Mestre em Psicologia pela PUC-RS. 
investigate if the practice of yoga influences the quality of life, well-being and emotional regulation, verifying the mental health of practitioners, the psychosocial importance in the individual's life, as well as the influence of yoga practice on the health promotion, on patients from a CAPS-II at the north coast of Rio Grande do Sul. This is a qualitative exploratory research. The instruments used were a sociodemographic questionnaire, semi-structured interview and Goldberg General Health Questionnaire - QSG 28. Six subjects that participated in the yoga workshop of a Psychosocial Care Center - CAPS-II of the north coast of Rio Grande do Sul take part in the research. The analysis of the interviews was performed using the Bardin's method and the QSG-28 according to the correction protocol. The results obtained showed that the yoga practitioners had emotional, physical, psychological and social benefits with the practice of yoga.

Keywords: Yoga. Quality of Life. Wellbeing. Emotional Regulation.

\section{INTRODUÇÃO}

O Ministério da Saúde aprovou no ano de 2006 a Política Nacional de Práticas Integrativas e Complementares (PNPIC), através da Portaria 971 de 03 de maio. No entanto, de início a Política implantou a utilização de poucas técnicas, tendo sido incrementada em 2017, com a portaria 849 de março, onde dentre outras técnicas, entrou o yoga.

A prática do yoga, segundo o Ministério da Saúde (2017) gera benefícios para o bem-estar físico e mental, nesse sentido, a PNPIC aparece na contramão do modelo biomédico hegemônico, o qual tem como tendência ignorar as práticas alternativas na promoção da saúde. Assim, as práticas alternativas e complementares objetivam um olhar mais subjetivo sobre o indivíduo, o considerando de uma forma mais integral, ou seja, essas práticas vêm com enfoque no biopsicossocial (MEDEIROS, 2017).

O aumento dos transtornos mentais na população é um fenômeno observável no mundo inteiro, dados da Organização Mundial da Saúde (2002) demonstram este fato, já que atualmente cerca de 450 milhões de pessoas sofrem de perturbações mentais ou comportamentais. No Brasil, O Ministério da Saúde aponta que 12\% da população geral carece de um atendimento em saúde mental, sendo este contínuo ou eventual e $3 \%$ da 
população apresenta transtornos mentais severos e persistentes (BRASIL, 2008 apud AGÊNCIA NACIONAL DE SAÚDE SUPLEMENTAR, 2008).

Visto o aumento dos transtornos mentais na população em geral, bem como, a implementação da prática de yoga na PNPIC, o presente estudo teve como objetivo investigar se a prática do yoga influencia na qualidade de vida, no bem-estar e na regulação emocional do indivíduo, verificando sua contribuição para a saúde mental de praticantes, a importância psicossocial na vida do indivíduo, bem como, a influência da prática de yoga na promoção de saúde de pacientes de um CAPS-II do Litoral Norte do Rio Grande do Sul.

\section{FUNDAMENTAÇÃO TEÓRICA}

\subsection{Yoga}

O yoga teve sua origem na tradição védica, sendo composto por posturas físicas, controle da respiração, controle das percepções corporais, concentração, meditação e controle da mente. Atualmente o yoga vem sendo entendido como uma prática psicofísica, onde seus praticantes obtém benefícios terapêuticos, tendo assim, despertado interesse da comunidade científica e, além disso, tem tido efeitos cada vez mais positivos na população em geral (MEDEIROS, 2017).

O Yoga tem como objetivo desenvolver o potencial do corpo de forma integrada com a mente, desta forma, auxilia na diminuição das dificuldades físicas e emocionais. Origina-se no Ocidente e é composto por posturas corporais, concentração, meditação, controle da respiração e inibição emocional. Há evidências de que sua prática propicia efeitos positivos, tais como, estado contínuo de energia, serenidade, autoconfiança, equilíbrio físico e emocional e, clareza emocional, portanto, diminui sintomas de ansiedade e estresse (BERNARDI et al, 2013).

Segundo Bernardi et al (2013), a prática do Yoga busca fazer o indivíduo tomar contato com seu corpo e com seu interior, de modo a propiciar exercícios de condução mental, que possibilitam alterações na forma e no foco dos pensamentos e leva a transformações emocionais, bem como, no funcionamento dos sistemas orgânicos do indivíduo, assim, este se apropria do seu processo de cura e bem-estar. 
Há algum tempo o Yoga vem se mostrando eficaz e eficiente na promoção de saúde dos indivíduos, além de ter baixos custos, também resulta em bons resultados em curto período de tempo, estudos comprovam que com três meses de prática, já se obtém importantes benefícios na saúde física e psíquica (PECANHA; CAMPANA 2010).

Contudo, apesar de todas essas evidências, a prática pode não alcançar o mesmo efeito positivo para todos os participantes, pois, para alcance dessas sensações é preciso perceber cada momento da prática, sem forçar o corpo a ir além do que suporta confortavelmente. Além disso, a implementação da prática não pretende substituir a conduta médica tradicionalmente utilizada, mas sim, de haver sua integração na promoção de saúde desses indivíduos (BERNARDI et al, 2013).

\subsection{Saúde Mental}

A definição de saúde mental perpassa pelos conceitos de bem-estar subjetivo, auto eficácia percebida, autonomia, competência e auto realização, sendo assim, a saúde mental passa a ser mais do que a ausência de doença e está intimamente ligada com a saúde física e com o comportamento. Portanto, conforme descrito pela Organização Mundial de Saúde OMS (2002), “A saúde é um estado de completo bem-estar físico, mental e social, e não consiste apenas na ausência de doença ou de enfermidade."

Esta definição sobre saúde da Organização Mundial da Saúde vem recebendo críticas, visto que, um "completo bem-estar" seria impossível de ser atingido em decorrência das limitações humanas e ambientais. Portanto, em decorrência destas críticas e ainda, de diversos eventos políticos e econômicos acerca do tema, surge um novo paradigma sobre o assunto, ou seja, a saúde como produção social, conceito este que vem como rejeição da abordagem higienista (GAINO, 2018).

No que tange a saúde mental, a Organização Mundial da Saúde (2002) a define como "um estado de bem-estar no qual um indivíduo percebe suas próprias habilidades, pode lidar com os estresses cotidianos, pode trabalhar produtivamente e é capaz de contribuir para sua comunidade [...]". Atualmente, se sabe que a saúde mental depende da combinação de fatores biológicos, psicológicos e sociais, ou seja, a saúde pode ser vista através do modelo biopsicossocial, em que diversos fatores interagem entre si e determinam o processo de saúde e doença. 
Diversos são os prejuízos trazidos pelos transtornos mentais, acarretando diminuição da qualidade de vida dos indivíduos, devido ao comprometimento funcional com consequente perda da produtividade no trabalho e isolamento social. Desta forma, há mais procura pelos atendimentos de saúde e por sua vez são produzidos custos elevados. Além disso, os transtornos mentais causam grande sofrimento individual e do grupo familiar como um todo (SENICATO et al 2018). Portanto, o aparecimento destes transtornos pode levar para além do sofrimento, mas também, a diminuição da qualidade de vida das pessoas afetadas (MURCHO et al, 2016).

\subsection{Promoção de Saúde}

Tendo em vista a ampliação do conceito de saúde, além da compreensão do processo saúde-doença, iniciou-se o processo de priorizar a visão de promoção de saúde. Este movimento teve início nos anos 70 no Canadá, após ter se verificado altos custos devido a abordagem exclusivamente médica tomada até então (BUSS, 2000). A partir disto, a promoção de saúde também começou a aparecer no âmbito da saúde pública, já que em 1986 é publicada a Carta de Ottawa para a Promoção de Saúde, onde essa é definida como: “[...] o processo de capacitar as pessoas para aumentar o controle sobre, e para melhorar, sua saúde [...]” (ORGANIZAÇÃO MUNDIAL DA SAÚDE, 1986).

O conceito atual de saúde tem seu foco no coletivo, ou seja, preza por ações de promoção de saúde e ainda, tem como objetivos intervenções que promovam a qualidade de vida e o bem-estar dos indivíduos. Além disso, a promoção de saúde advém com a premissa de que os comportamentos do indivíduo causam impactos sobre sua saúde e que mudanças saudáveis podem melhorá-la, portanto, este conceito acaba por responsabilizar o indivíduo e a comunidade (SILVA \& HELENO, 2012).

Neste contexto, a saúde pode ser vista através do modelo biopsicossocial, qual seja, interação entre fatores biológicos, psicológicos e sociais, em que diversos fatores interagem entre si e determinam o processo de saúde e doença. Por fim, a saúde mental é entendida pela Organização Mundial da Saúde (2002) como sendo tão importante quanto à saúde física, visto que gera bem-estar aos indivíduos e à sociedade.

Dentre as estratégias estabelecidas pela Organização Mundial da Saúde (2002) para investimento na saúde mental da população, são descritas estratégias de promoção à saúde, 
assim como: “[...] assegurar o acesso universal a serviços apropriados e econômicos, inclusive serviços de promoção da saúde mental e de prevenção; promover estilos de vida saudáveis [...]; apoiar uma vida familiar estável, a coesão social e o desenvolvimento humano.”

\subsubsection{Qualidade de Vida}

No âmbito da saúde a qualidade de vida é tida como um conceito amplo, que vai desde a compreensão das necessidades humanas fundamentais até a promoção da saúde, visto que desta forma haverá também a promoção da qualidade de vida (MINAYO et al, 2000). Outro autor acrescenta que fatores de vida positivos favorecem a qualidade de vida, assim, estes podem ser fortalecidos através de estratégias criadas para mantê-los e, em contrapartida, os fatores de vida negativos devem ser enfraquecidos (OLIVEIRA, 2006).

Qualidade de vida foi definida pela Organização Mundial da Saúde como sendo a percepção do indivíduo acerca da sua posição na vida, ou seja, em sua cultura, dentro do sistema de valores em que vive e com relação aos seus objetivos e expectativas, assim como, seus padrões e preocupações. Conceito este muito utilizado nos dias atuais, devido a sua ampla definição abrangendo fatores de inter-relação de aspectos ambientais, sociais, psicológicos, físicos e de independência (SILVA \& HELENO, 2012).

Por fim, Minayo, Hartz e Buss (2000) esclarecem sobre o conceito de qualidade de vida: "O termo abrange muitos significados, que refletem conhecimentos, experiências e valores de indivíduos e coletividades que a ele se reportam em variadas épocas, espaços e histórias diferentes, sendo, portanto, uma construção social com a marca da relatividade cultural."

\subsubsection{Bem-estar}

O conceito de bem-estar é recente, por volta dos anos sessenta e é considerado complexo, compreendendo fatores cognitivos e afetivos, além de englobar outros conceitos, assim como, a qualidade de vida, emoções negativas e emoções positivas. Assim, o bem-estar está associado a presença de emoções positivas, ausência de emoções negativas e presença de sentimentos de satisfação com a vida (RIBEIRO \& GALINHA, 2005). 
A psicologia positiva se detém a estudar o bem-estar e o descreve como sendo um facilitador da maneira positiva como as pessoas enxergam a si e aos outros, fortalecendo assim, o relacionamento com os pares, pois, proporcionam um maior prazer em vivenciar as situações cotidianas (PASSARELI \& SILVA, 2007).

A satisfação com a vida refere-se a um conceito de julgamento cognitivo de avaliação geral da própria vida, o afeto positivo ligado a sentimentos agradáveis, de entusiasmo e prazer e, o afeto negativo ligado a emoções desagradáveis, assim como, de aborrecimento, ansiedade, angústia e pessimismo. Ambos, afetos negativos e afetos positivos são estados emocionais transitórios (ALBUQUERQUE \& TRÓCCOLI, 2004).

\subsection{Regulação Emocional}

As emoções de modo geral influenciam na qualidade de vida dos indivíduos, visto que estão diretamente relacionadas a como ocorrem os relacionamentos, no âmbito profissional, familiar, de amizades e nos relacionamentos amorosos. Nesse sentido, as emoções podem ser consideradas tendências de respostas comportamentais, experienciais e fisiológicas, as quais, de forma conjunta resultam na maneira como as pessoas se comportam diante de situações significativas (FELICORI, 2017).

Portanto, as emoções devem ser compreendidas como um conjunto de processos, ou seja, diante de uma emoção deve haver avaliação de uma situação, sensação corporal, intencionalidade, comportamento motor e, por fim, o relacionamento interpessoal. Neste sentido, quando a pessoa apresenta a emoção ansiedade, ela pode estar preocupada em não conseguir concluir uma tarefa a tempo, pode apresentar sudorese e ritmo cardíaco acelerado, se concentrar mais para terminar a tempo, ficar inquieto e se relacionar de uma maneira inadequada com as pessoas a sua volta (LEAHY et al, 2013).

Importante salientar que a regulação emocional, segundo Leahy et al (2013), pode incluir qualquer estratégia de enfrentamento, sendo ela adaptativa ou desadaptativa, que o indivíduo faz uso para lidar com a emoção intensificada. Por meio da regulação emocional o indivíduo busca regular suas emoções, através do autocontrole, da expressão das emoções e dos sentimentos, do reconhecimento e nomeação das suas emoções e das emoções dos outros, da tolerância a frustração e do reconhecimento dos fatores positivos de cada situação vivenciada. A regulação emocional, ou seja, o controle das emoções, se faz necessário quando 
as emoções experienciadas não são compatíveis com as situações, já que, as emoções mal reguladas podem gerar elevado mal-estar. Pesquisas apontam que a regulação das emoções proporciona maior bem-estar e melhor funcionamento do indivíduo de um modo geral (FELICORI, 2017).

A capacidade que o indivíduo demonstra de regular as suas emoções resulta em saúde mental, ou seja, promove um funcionamento emocional e psicossocial saudável e adaptativo. Nesse sentido, essa capacidade está atrelada ao desenvolvimento de competências sociais, assim como, o estabelecimento de relações saudáveis. Em contrapartida, a desregulação emocional, ou seja, a falta de estratégias para lidar com as emoções intensificadas, é característica presente em mais da metade dos transtornos mentais descritos no DSM -V Manual Diagnóstico e Estatístico dos Transtornos Mentais (SILVA \& FREIRE, 2014).

\section{METODOLOGIA}

\subsection{Delineamento}

Pesquisa qualitativa de caráter exploratório. De acordo com Gil (2010) esse tipo de pesquisa tem como objetivo proporcionar maior familiaridade com assunto que será investigado, com a finalidade de torná-lo mais explícito.

\subsection{Participantes}

A pesquisa foi realizada com 06 pacientes participantes da oficina de yoga de um Centro de Atenção Psicossocial - CAPS-II do Litoral Norte do Rio Grande do Sul, serviço especializado mantido pela prefeitura municipal para atender a clientela do SUS.

O grupo é formado por pacientes usuários do CAPS de ambos os sexos, com faixa etária de 20 à 70 anos de idade. Os critérios para participação da presente pesquisa incluem ser alfabetizado e estar frequentando a oficina de forma assídua por, no mínimo, dois meses.

A oficina de yoga ocorreu uma vez por semana no turno da tarde, em lugar calmo, com a utilização de canga de praia e/ou colchonete, assim como, um aparelho de som como material de apoio. Os encontros duraram uma hora e tiveram como objetivos um momento de acolhimento e interiorização dos indivíduos voluntários, conscientização da respiração 
diafragmática, realização de posturas corporais, realização de exercícios respiratórios, relaxamento e exercícios de concentração preparatórios para a meditação.

\subsection{Instrumentos de coleta de dados}

Os instrumentos selecionados para a coleta de dados foram o questionário sócio demográfico, entrevista semiestruturada - com questões norteadoras, conforme o assunto explorado e o Questionário de Saúde Geral de Rosenberg - QSG - 28.

\subsubsection{Questionário de dados sociodemográficos}

Foi utilizado um questionário estruturado para coletar informações acerca do perfil sociodemográfico dos participantes da pesquisa.

\subsubsection{Entrevista semiestruturada}

Foi realizada uma entrevista semiestruturada baseada em roteiro temático pré-definido. A entrevista foi baseada em perguntas semi abertas, possibilitando aos entrevistados expressar o entendimento dessas experiências em suas próprias palavras. As entrevistas foram gravadas e, posteriormente, transcritas para a análise do seu conteúdo, assim como descreve Bardin (2011).

Os tópicos principais a serem abordados na entrevista serão: motivos que levaram o indivíduo a iniciar a prática do yoga, benefícios que identifica após o início da prática, percepção da qualidade de vida e do bem-estar após a prática do yoga, mudanças que observou nas interações sociais após a prática, se passou a perceber as emoções, se mudou as estratégias para lidar com as emoções negativas intensas e se houve mudanças no modo como expressa suas emoções após a prática do yoga.

\subsubsection{Questionário de Saúde Geral - QSG - 28}

O Questionário de Saúde Geral foi originalmente desenvolvido por Goldberg em 1979. Trata-se de um questionário de auto resposta, apropriado para avaliar a saúde mental ou o 
bem-estar psicológico do avaliando, sendo utilizado para detectar a existência de provável perturbação psiquiátrica, ou seja, avalia o estado atual do indivíduo e identifica se este estado difere do seu estado habitual, sendo que este é um dos instrumentos mais utilizados no rastreio de saúde mental. A versão do QSG - 28 demonstra ser adequada para detectar os tipos sintomáticos de ansiedade, insônia, disfunção social, sintomas psicossomáticos e depressão grave (GORESTEIN; WANG; HUNGERBÜHLER, 2016).

O questionário é composto por 28 itens, os quais foram divididos em quatro subescalas, compreendendo quatro dimensões, dispostas da seguinte forma: questões de 01 a 07, estão relacionadas à sintomas psicossomáticos; as questões de 08 a 14, à ansiedade e insônia; as questões de 15 a 21, à disfunção social e de 22 a 28, à depressão grave. Para cada questão existem quatro alternativas, onde a pontuação do questionário foi realizada no tipo Likert, ou seja, foram atribuídas notas para cada uma, sendo 0-1-2-3. A pontuação tipo Likert é uma das propostas mais utilizadas, pois, permite investigar a gravidade dos sintomas. Ao final os itens foram somados para se obter um escore para cada dimensão. $\mathrm{O}$ valor de corte considerado é o quatro, sendo que valores acima já indicam a presença de um caso psiquiátrico (GORESTEIN; WANG; HUNGERBÜHLER, 2016).

\subsection{Procedimentos da coleta de dados}

Inicialmente, após a construção do projeto, entrou-se em contato com o CAPS para verificação da disponibilidade de realização da pesquisa no local. Após a aprovação do projeto no comitê de ética, a pesquisadora entrou em contato com o CAPS do município de Tramandaí para obter autorização da coordenação do serviço para convidar os indivíduos para participar da pesquisa. Em continuidade, a coleta dados foi agendada através de ligação telefônica, verificando dia e horário de acordo com a preferência de cada participante. A aplicação do questionário (QSG - 28), realização da entrevista semiestruturada e coleta de dados sociodemográficos foi realizada no CAPS Viva a Vida de Tramandaí, com duração máxima de uma hora para cada participante da pesquisa. No primeiro contato com a coordenadora do estudo, os indivíduos foram devidamente instruídos sobre os objetivos da pesquisa e após assinaram o Termo de Consentimento Livre e Esclarecido - TCLE.

\subsection{Análise dos dados}


Após a coleta das entrevistas, a mesmas foram transcritas e após foram criadas categorias para análise dos dados de acordo com o método de análise de conteúdo de Bardin (2011), a fim de responder a problemática levantada por este estudo. Os resultados do questionário foram levantados conforme protocolo de correção do instrumento.

\subsection{Considerações éticas}

A pesquisa trata-se do trabalho de conclusão de curso desta graduanda, tendo como professor orientador Ms. Dionéia Luciane Mendes e foi submetido ao Comitê de Ética em Pesquisa do Centro Universitário Cenecista de Osório, tendo como número de parecer 3.634.924. Esta pesquisa foi realizada no único Centro de Atenção Psicossocial do município de Tramandaí (CAPS-II Viva a Vida). As informações foram coletadas de forma individual, sem qualquer prejuízo para as pessoas envolvidas, especialmente no que diz respeito aos dados pessoais dos pacientes. Os dados coletados estão sob a guarda da pesquisadora (Luana Felício da Silva Dariva) e de sua orientadora (Prof. Ms. Dionéia Luciane Mendes) por cinco anos, sendo garantido seu sigilo e confidencialidade. Os dados serão destruídos cinco anos após a finalização do presente estudo.

Todos os participantes foram convidados a assinar um Termo de Consentimento Livre e Esclarecido para a autorização da coleta e análise dos dados, cientes que as informações geradas seriam divulgadas, via relatório e publicações, seguindo os princípios éticos da pesquisa em saúde.

\section{RESULTADOS}

Na tabela 01 foram apresentados os resultados obtidos através do questionário sócio demográfico que caracteriza os sujeitos participantes desta pesquisa.

Tabela 1 - Dados Sócio Demográficos:

\begin{tabular}{ccccccc}
\hline & P01 & P02 & P03 & P04 & P05 & P06 \\
\hline Idade & 60 anos & 65 anos & 42 anos & 69 anos & 55 anos & 70 anos \\
\hline Sexo & Feminino & Feminino & Feminino & Feminino & Feminino & Feminino \\
\hline
\end{tabular}


Tabela 01 - Dados Sócio Demográficos

(continuação)

\begin{tabular}{|c|c|c|c|c|c|c|}
\hline Escolaridade & $\begin{array}{l}\text { Técnico } \\
\text { Completo }\end{array}$ & $\begin{array}{c}\text { Médio } \\
\text { Incompleto }\end{array}$ & $\begin{array}{l}\text { Fundamental } \\
\text { Incompleto }\end{array}$ & $\begin{array}{c}\text { Fundamental } \\
\text { Completo }\end{array}$ & $\begin{array}{l}\text { Superior } \\
\text { Completo }\end{array}$ & $\begin{array}{l}\text { Fundamental } \\
\text { Incompleto }\end{array}$ \\
\hline Estado Civil & Casada & Divorciada & Casada & Casada & Casada & Viưva \\
\hline $\mathrm{N}^{\circ}$ filhos & 02 & 03 & 01 & 01 & 03 & 02 \\
\hline $\begin{array}{c}\text { Com quem } \\
\text { mora }\end{array}$ & Cônjuge & Sozinha & $\begin{array}{l}\text { Cônjuge e } \\
\text { filhos }\end{array}$ & Cônjuge & $\begin{array}{l}\text { Cônjuge e } \\
\text { filhos }\end{array}$ & Sozinha \\
\hline $\begin{array}{l}\text { Renda } \\
\text { familiar }\end{array}$ & 02 salários & 01 salário & 02 salários & $\begin{array}{c}02 \text { salários e } \\
\text { meio }\end{array}$ & 02 salários & 01 salário \\
\hline $\begin{array}{c}\text { Situação } \\
\text { ocupacional }\end{array}$ & Aposentada & Aposentada & Empregada & Aposentada & Aposentada & Aposentada \\
\hline Diagnóstico & Depressão & Depressão & $\begin{array}{c}\text { Em } \\
\text { tratamento } \\
\text { para a saúde } \\
\text { mental }\end{array}$ & Depressão & $\begin{array}{l}\text { Depressão } \\
\text { com } \\
\text { sintomas } \\
\text { psicóticos }\end{array}$ & $\begin{array}{c}\text { Em } \\
\text { tratamento } \\
\text { para a saúde } \\
\text { mental }\end{array}$ \\
\hline Psicoterapia & $\begin{array}{c}1 \text { ano e } 6 \\
\text { meses }\end{array}$ & 1 ano & Não & $\begin{array}{c}2 \text { anos e } 5 \\
\text { meses }\end{array}$ & 2 meses & $\begin{array}{c}2 \text { anos e } 5 \\
\text { meses }\end{array}$ \\
\hline Psicofármacos & Sertralina & $\begin{array}{l}\text { Citalopram } \\
\text { Naltrexona }\end{array}$ & Citalopram & $\begin{array}{c}\text { Clonazepam } \\
\text { Fluoxetina }\end{array}$ & $\begin{array}{c}\text { Citalopram } \\
\text { Zolpidem } \\
\text { Egide }\end{array}$ & Não \\
\hline $\begin{array}{c}\text { Tempo } \\
\text { (fármacos) }\end{array}$ & 1 ano & $\begin{array}{c}1 \text { ano e } 6 \\
\text { meses }\end{array}$ & 6 meses & 10 anos & 6 anos & - \\
\hline $\begin{array}{c}\text { Início do } \\
\text { Yoga }\end{array}$ & 2 meses & 2 meses & 2 meses & 2 meses & 2 meses & 2 meses \\
\hline
\end{tabular}

Fonte: Elaborado pela autora, 2019.

A pesquisa foi realizada com seis indivíduos participantes da oficina de yoga de uma CAPS II, que estavam praticando a atividade de yoga por pelo menos dois meses. Através dos dados obtidos na Tabela 01 se pode observar que todas as participantes da pesquisa são mulheres com idades entre 42 anos e 70 anos. No que tange a escolaridade, duas apresentam ensino fundamental incompleto, uma ensino fundamental completo, uma com ensino médio incompleto, uma com ensino técnico completo e uma com ensino superior completo. Destas, quatro são casadas, uma divorciada e uma viúva, sendo que todas as seis tiveram pelo menos um filho. Duas participantes relataram morar apenas com cônjuge, duas com cônjuge e filho e, duas sozinhas. A renda familiar dos entrevistados varia de um salário mínimo à dois salários mínimos e meio, sendo que das seis entrevistadas, cinco então aposentadas e uma empregada. Quanto ao diagnóstico, P01, P02 e P04 foram diagnosticadas com depressão, P05 tem diagnóstico de depressão com sintomas psicóticos, P03 e P06 estão em atendimento para saúde mental. Das entrevistadas cinco delas fazem uso de psicofármacos, com tempos 
variados de 6 meses até 10 anos de uso. Cinco participantes realizam psicoterapia semanal atualmente, sendo que P05 iniciou há 2 meses e as demais estão a pelo menos 1 ano no processo terapêutico. E todas as pesquisadas iniciaram a prática do yoga a aproximadamente dois meses.

Na tabela 02 será mostrado o nível de saúde geral dos praticantes do yoga obtido através do Questionário de Saúde Geral de Goldberg (QSG-28).

Tabela 02 - Questionário de Saúde Geral de Goldberg (QSG-28):

\begin{tabular}{|c|c|c|c|c|c|c|}
\hline & P01 & P02 & $\mathrm{P} 03$ & P04 & P05 & $\mathrm{P} 06$ \\
\hline $\begin{array}{c}\text { Sintomas } \\
\text { psicossomáticos }\end{array}$ & $\mathrm{Sim}$ & Não & $\mathrm{Sim}$ & Não & Não & Não \\
\hline Pontuação & 05 & 01 & 09 & 01 & 01 & 00 \\
\hline $\begin{array}{l}\text { Ansiedade e } \\
\text { insônia }\end{array}$ & Sim & Não & $\mathrm{Sim}$ & Não & Não & Não \\
\hline Pontuação & 08 & 01 & 09 & 00 & 02 & 00 \\
\hline $\begin{array}{l}\text { Disfunção } \\
\text { Social }\end{array}$ & Sim & Não & Sim & Não & Não & Não \\
\hline
\end{tabular}

Tabela 02 - Questionário de Saúde Geral de Goldberg (QSG-28)

(continuação)

\begin{tabular}{ccccccc}
\hline Pontuação & 06 & 02 & 10 & 01 & 00 & 04 \\
\hline $\begin{array}{c}\text { Depressão } \\
\text { Grave }\end{array}$ & $\operatorname{Sim}$ & Não & Sim & Não & Não & Não \\
Pontuação & 08 & 00 & 20 & 01 & 02 & 02 \\
\hline
\end{tabular}

Fonte: Elaborado pela autora, 2019.

Através dos dados obtidos no Questionário de Saúde Geral de Goldberg (QSG-28), descritos na tabela 2, podemos constatar que P01 e P03 demonstraram ter todos os sintomas medidos pelo questionário e as demais participantes não apresentaram nenhum dos sintomas medidos pelo questionário. Assim, P01 e P03 demonstraram apresentar sintomas psicossomáticos, ansiedade, insônia, disfunção social e depressão grave (pontuação superior ao ponto de corte 04), já P02, P04, P05 e P06 não apresentaram os sintomas referidos (pontuação igual ou menor que o ponto de corte 04).

Para a análise das entrevistas foi utilizado o método de análise de conteúdo de Bardin (2011) sendo criadas categorias, conforme seguem:

$\mathrm{Na}$ categoria motivo do início da prática do yoga foi analisado a história do participante referente ao motivo que o levou a iniciar a prática do yoga (Quadro 01). 
Quadro 01 - Motivo do Início da Prática do Yoga

\begin{tabular}{|c|c|}
\hline P 01 & $\begin{array}{l}\text { "Ah, pela facilidade de estar aqui no CAPS né e saber que ia ter esse grupo do yoga e, acho que } \\
\text { para alongar a musculatura, reloxar, me ocupar... ai eu quis, eu quis porque, não sei né, eu penso } \\
\text { assim que se eu fizer o yoga que é alongamento assim, que são exercicios pra mente, pode me } \\
\text { acalmar, me relaxar [...]" (sic). }\end{array}$ \\
\hline $\mathrm{P} 02$ & $\begin{array}{l}\text { "Conversando com o Psicólogo que eu tenho grupo terapia nas sextas-feiras [...] ]ai ele comentoue } \\
\text { como sempre eu ouvi falar que era uma coisa boa, ai eu resolvi praticar [...]" (sic). }\end{array}$ \\
\hline $\mathrm{P} 03$ & $\begin{array}{l}\text { "É que dai eu vim aqui, fiz o acolhimento e eles me chamaram pro yoga, embora eu tivesse pedido } \\
\text { um psicólogo. O yoga me ajuda bastante assim né, no momento que a gente está aqui, tu relaxa, tu } \\
\text { esquece o mundo lá fora né, é maravilhoso assim, mas é aquela necessidade que tu tem de } \\
\text { conversar, de esclarecer dúvidas sabe, que nem um psicólogo que te ajuda nesse sentido né, mas } \\
\text { o yoga é maravilhoso[... Jatualmente eu estou fazendo só o yoga[...]" (sic). }\end{array}$ \\
\hline P 04 & $\begin{array}{l}\text { "Eu sentia dores no joelho né, no pescoço, nos braços, eu não podia dormir por cima do braço } \\
\text { sabe e sempre me falavam né, que se eu fizesse alguma atividade assim, o yoga ia me passar e aí } \\
\text { surgiu né, o Psicólogo falou ali que se alguém se interessasse, eu fui a primeira né a levantar o } \\
\text { dedo, fui a primeira mesmo a vir no grupo. [...] Olha, muito bom, muito bom mesmo, eu sempre } \\
\text { tive o sonho de fazer yoga, só que o dinheiro não dava né. [...] pra mim foi muito bom mesmo né } \\
\text { porque eu me sinto melhor, eu me sinto bem melhor néf...]" (sic). }\end{array}$ \\
\hline P 05 & $\begin{array}{l}\text { "Eu acho que eu senti necessidade de me comunicar em grupo, de ter uma vida social um } \\
\text { pouquinho melhor assim porque eu estava me sentindo muito isolada, eu estava muito antissocial. } \\
\text { Ai como sempre o yoga foi uma coisa que me chamou a atenção porque eu sempre gostei muito do } \\
\text { budismo onde tem prática de concentração, de relaxamento e tudo, então eu sabia que também } \\
\text { tinha a ver com o yoga né, então foi por isso acho que já por simpatizar assim [...]" (sic). }\end{array}$ \\
\hline P 06 & $\begin{array}{l}\text { "A psicóloga disse para mim que eu tinha que fazer alguma coisa né, para me distrair, não ficar } \\
\text { em casa muito [...] então, eu vim aqui, achei que elas me deram bastante atenção, me incentivaram. } \\
\text { Eu fiz a entrevista e ela disse ah vamos fazer o yoga que é bom né }[. . .7 \text {. (sic). }\end{array}$ \\
\hline
\end{tabular}

Fonte: Elaborado pela autora, 2019.

$\mathrm{Na}$ categoria dores e doenças físicas buscou-se analisar se os praticantes do yoga possuíam doenças físicas, bem como, se havia a presença de dores antes do início da prática do yoga (Quadro 02).

Quadro 02 - Dores e Doenças físicas

\begin{tabular}{l|l} 
P 01 & "Realmente eu tenho problemas na lombar e no ciático. Tenho também Psoríase há mais de dez
\end{tabular} anos e se acentuou há uns dois anos [...]" (sic).

Quadro 02 - Dores e Doenças físicas

(continuação) 


\begin{tabular}{|c|l|}
\hline P 02 & $\begin{array}{l}\text { "Eu tenho problema de hérnia de disco que de noite eu deitava parecia que eu tinha uma coisa que } \\
\text { dava aqueles beliscões e puxava. Tenho pressão alta também [...]" (sic). }\end{array}$ \\
\hline P 03 & "Não tenho nenhuma[...]" (sic). \\
\hline P 04 & $\begin{array}{l}\text { "Eu sentia dores no joelho né, no pescoço, nos braços, eu não podia dormir por cima do braço } \\
\text { sabe[...]" (sic). }\end{array}$ \\
\hline P 05 & "Eu tenho asma né[...]" (sic). \\
\hline P 06 & $\begin{array}{l}\text { "Eu sinto as dores né, dos parafusos que eu tenho na coluna. Tenho tendinite, diabetes e sou } \\
\text { soropositivo[...]" (sic). }\end{array}$ \\
\hline
\end{tabular}

Fonte: Elaborado pela autora, 2019.

$\mathrm{Na}$ categoria benefícios físicos oriundos da prática do yoga foram analisados os principais benefícios que os participantes observaram em sua saúde física após iniciar a prática do yoga (Quadro 03). 
Quadro 03 - Benefícios físicos oriundos da prática do yoga:

\begin{tabular}{|c|c|}
\hline P 01 & $\begin{array}{l}\text { "Agora com o yoga eu tenho percebido que realmente eu tenho problemas na lombar e no ciático, } \\
\text { então, o yoga ajuda? Ajuda, mas não está sendo o suficiente[...jagora clareou outras situaçóes. } O \\
\text { yoga me estimula a ter que ir numa academia, por uma questão de saúde, eu tenho vontade e eu } \\
\text { vejo necessidade fisica [...]" (sic). }\end{array}$ \\
\hline $\mathrm{P}_{02}$ & $\begin{array}{l}\text { "Maravilhoso! Eu tenho problema de hérnia de disco que de noite eu deitava parecia que eu tinha } \\
\text { uma coisa que dava aqueles beliscóes e pwoxava, desde que eu comecei a fazer o exercício de } \\
\text { yoga[...] de dia eu não sentia nada, mas de noite quando eu deitava parece que eu corpo tá mais } \\
\text { leve sabe? Eu sentia, não tô sentindo mais, tó adorando, tá maravilhoso, maravilhoso mesmo[...]" } \\
\text { (sic). }\end{array}$ \\
\hline P 03 & $\begin{array}{l}\text { "Ah ela me traz assim mais tranquilidade, mais paz, parece que tu te tranquiliza, mas é que nem } \\
\text { eu digo né, no momento que tu tá aqui a coisa assim vai que é uma maravilha né, tu te fecha assim } \\
\text { pro mundo lá fora, tu fica aqui dentro, tu fica assim sabe, mas daí tu sai e volta aquilo tudo, tu se } \\
\text { depara com a realidade lá na rua, aquela coisa assim sabe, mas eu gosto bastante do yoga, bem } \\
\text { bom mesmo, é ótimo[...]" (sic). }\end{array}$ \\
\hline P 04 & $\begin{array}{l}\text { "Eu não passo mais pomada no joelho e eu durmo em cima desse meu braço aqui, que até parece } \\
\text { que saiu o osso, porque eu tinha uma ponta de um osso aqui né e eu não sinto mais dor assim pra } \\
\text { dormir, nada, eu durmo e eu tenho bico de papagaio aqui no pescoço e eu não sinto mais dor, eu } \\
\text { durmo bem melhor depois que eu estou fazendo, meu Deus olha pra mim foi um, bah [...]" (sic). }\end{array}$ \\
\hline P 05 & $\begin{array}{l}\text { "Assim no corpo eu noto no estado fisico que eu tô, eu sinto que eu tô mais alongada, que eu tenho } \\
\text { mais flexibilidade, que eu me sinto bem melhor assim com mais facilidade eu consigo acompanhar } \\
\text { as posições, fazer os alongamentos, isso eu noto que melhorou bastante. A minha respiraçáo } \\
\text { também eu noto que melhorou, eu tenho asma né e tem me dado bem menos crise e tudo né. Até a } \\
\text { semana retrasada não teve, era feriado e eu senti a diferença assim sabe, senti falta assim, } \\
\text { bastante, porque ai na outra semana, ou seja, na semana passada teve e ai eu já senti um pouquinho } \\
\text { de dificuldade para me concentrar, parece que meio que fiquei[... J me fez falta aquela semana que } \\
\text { não teve, isso que é uma vez por semana né[...]" (sic). }\end{array}$ \\
\hline P 06 & $\begin{array}{l}\text { "Como eu tenho que caminhar, eu sinto as dores né, dos parafusos que eu tenho, mas ela desfaz } \\
\text { devagarinho e eu senti que o corpo também reloxei bem. Depois que eu comecei o yoga eu notei } \\
\text { que eu não tô mais sentindo dor, não me canso mais, então eu tô adorando vim/...]" (sic). }\end{array}$ \\
\hline
\end{tabular}

Fonte: Elaborado pela autora, 2019.

$\mathrm{Na}$ categoria benefícios psicológicos oriundos da prática do yoga foram analisados os principais benefícios psicológicos que os participantes observaram em suas vidas após iniciar a prática do yoga (Quadro 04).

Quadro 04 - Benefícios psicológicos oriundos da prática do yoga:

P 01 "Ah eu acho que acalma, parar, pensar e deixar pra lá, mas eu acredito que quando a gente medita, quando a gente para e pensa, a gente pode criar uma imagem melhor pra nós e hoje eu penso nas coisas. O pensamento vem, mas eu fico nele se eu quero, eu posso levantar, dar uma volta, espairecer ou só ficar em silêncio, que a gente aprende quando faz o relaxamento a silenciar ou

Quadro 04 - Benefícios psicológicos oriundos da prática do yoga.

(continuação) 


\begin{tabular}{|c|c|}
\hline & $\begin{array}{l}\text { viajar, viajar com o pensamento. Então faz bem, porque pra mim é uma contimuação da } \\
\text { terapial...J" (sic). }\end{array}$ \\
\hline $\mathrm{P} 02$ & $\begin{array}{l}\text { "ÉE que nem eu te digo é tanto na cabeça, como no corpo fisicamente, a gente se sente } \\
\text { melhor [...] mais relaxada, mais aliviada, é muito bom. } \hat{E} \text { muito bom pra cabeça da gente também } \\
\text { né, os relaxamentos que a gente faz são maravilhosos [....]" (sic). }\end{array}$ \\
\hline P 03 & $\begin{array}{l}\text { "Ai é que nem eu digo o yoga é maravilhoso, tu vem aqui e tu esquece o problema, mas daí tu } \\
\text { chega dentro de casa e tem todos esses problemas sabe, dai não tem como tu dizer assim, ah eu } \\
\text { vou ficar com a cabeça no yoga sabe, eu vou contimuar do jeito que eu sai de lá, porque não tem, } \\
\text { então...é que nem eu disse sabe, se meu problema não fosse dentro de casa seria uma maravilha } \\
\text { né, só o yoga, mas eu acho que eu precisaria de um acompanhamento psicológico também[...]" } \\
\text { (sic). }\end{array}$ \\
\hline P 04 & $\begin{array}{l}\text { "Estou assim tranquila e pra dormir é um sonho porque a gente sai muito tranquila daqui, muito } \\
\text { tranquila sabe. Mas olha, o yoga pra mim foi assim, um alivio assim que olha, eu saio daqui depois } \\
\text { daquele relaxamento que ela faz com a gente eu chego a chorar, sabe, porque ela leva a gente ir } \\
\text { nos lugares que a gente não imagina ir, entendeu, ela faz a gente ir lá, mas lá no fundo, caminhar, } \\
\text { ela faz tudo assim, eu chego a chorar. Olha, melhorei assim uns } 90 \% \text {. Na hora do reloxamento eu } \\
\text { posso até chorar um pouquinho, ela diz pode chorar a vontade, se quiser chorar pode chorar a } \\
\text { vontade, coloca pra fora e em casa eu fico tranquila, isso ai que é o bom. Até meu esposo notou } \\
\text { que eu estou bem mais calma[...]" (sic). }\end{array}$ \\
\hline P 05 & $\begin{array}{l}\text { "Mas eu acredito que também no psicológico ajudou bastante a meditação que a gente faz ali, o } \\
\text { relaxamento, me ajudou bastante, eu acredito que tenho conseguido controlar melhor a ansiedade, } \\
\text { eu era uma pessoa muito ansiosa, muito ansiosa e eu acho que com as práticas assim, através das } \\
\text { práticas de respiração e meditação eu acho que eu consigo controlar melhor, eu não me sinto mais } \\
\text { tão ansiosa. Mudou muito assim, que na verdade eu vou te dizer, só tomo esses remédios porque } \\
\text { eu não tenho quase contato com a Psiquiatra, que é dificil conseguir consulta, porque eu acho } \\
\text { assim se eu tivesse um acompanhamento mais constante com a psiquiatra já tinha diminuido } \\
\text { bastante essa medicação entendeu, porque tô me sentindo muito melhor [...]" (sic). }\end{array}$ \\
\hline P 06 & $\begin{array}{l}\text { "Ah eu achei assim que eu relaxo, a hora que ela manda a gente deitar e relaxar. Também tô mais } \\
\text { animada né. Eu adorei fazer, tomara que tenha sempre [...]" (sic). }\end{array}$ \\
\hline
\end{tabular}

Fonte: Elaborado pela autora, 2019.

$\mathrm{Na}$ categoria mudanças no bem-estar e na qualidade de vida relacionadas a prática do yoga foi apresentado a percepção dos participantes sobre os benefícios relacionados ao bem-estar e qualidade de vida após o início da prática do yoga (Quadro 05).

Quadro 05 - Mudanças no Bem-Estar e na Qualidade de Vida Relacionadas a Prática do Yoga: 


\begin{tabular}{|c|c|}
\hline P 01 & $\begin{array}{l}\text { "A minha percepção de coisas boas aumentou[...] É uma questão da gente saber, de eu conseguir } \\
\text { me ver, ver onde eu estou melhorando, eu acho que sim, eu estou sim sempre tem, no decorrer do } \\
\text { dia eu penso assim: Ah, isso a gente pensa lá no yoga, a gente faz lá no yoga, a gente conversa lá } \\
\text { no yoga }[. . .] " \text { (sic). }\end{array}$ \\
\hline P 02 & $\begin{array}{l}\text { "Mudou praticamente tudo né .,. no bem-estar, no se sentir bem, bem mesmo. Me sinto bem melhor } \\
\text { para dormir principalmente. É o que eu digo né, ela te relaxa, fisicamente a gente fica mais } \\
\text { relaxada, to muito bem mesmo, muito bem[-...]" (sic). }\end{array}$ \\
\hline $\mathrm{P} 03$ & $\begin{array}{l}\text { "É, é o que eu te falei né, enquanto eu tô aqui tá maravilhoso, mas é que o meu problema está } \\
\text { dentro de casa. Ai acho que não, foi quem nem eu disse, o momento meu éo momento que eu estou } \\
\text { aqui, eu saio daqui não[...]sabe, não mudou nada, mas no momento que eu tô aqui tá bom, tá bem } \\
\text { assim acolhedor [...]" (sic). }\end{array}$ \\
\hline P 04 & $\begin{array}{l}\text { "Eu me sinto bem mais tranquila, eu comecei a ler livros, eu comecei a tirar uma sonequinha meio- } \\
\text { dia, fico bem tranquila, faço o almoço tranquila, lavo a minha louça e dou uma deitadinha. Antes } \\
\text { eu era aflita, eu era[...Jsabe, eu me incomodava por qualquer coisa sabe, com meu esposo ou } \\
\text { comigo mesmo, qualquer coisa eu me incomodava e depois do yoga eu estou bem mais tranquila, } \\
\text { sei lá, é muito bom, é o relaxamento eu acho e os exercicios também fazem muito bem pra gente } \\
\text { nél...l" (sic). }\end{array}$ \\
\hline P 05 & $\begin{array}{l}\text { "Melhorou bastante, claro, nessas questões que eu te falei né, assim, eu acho que eu consigo } \\
\text { dormir melhor porque dai eu faço a prática de relaxamento, através destas práticas assim que o } \\
\text { yoga ensina né, eu acho que melhorou bastante sim, me sinto com mais disposição também. Bah } \\
\text { no dia então que eu venho e pratico com o grupo, mas, eu saio muito bem, me sinto mais leve, mais }\end{array}$ \\
\hline
\end{tabular}

Quadro 05 - Mudanças no Bem-Estar e na Qualidade de Vida Relacionadas a Prática do Yoga.

(continuação)

\begin{tabular}{|c|l|}
\hline \multirow{6}{*}{ P 06 } & $\begin{array}{l}\text { relaxada, mais, sei lá, mais positiva. Eu não me sinto mais tão ansiosa. E eu acho que o beneficio } \\
\text { maior de tu não te sentir tão ansiosa, é que tu tem uma qualidade de vida bem melhor, como é que } \\
\text { eu vou te dizer, não sei como te explicar, mas é que tu consegue te concentrar melhor, nas coisas, } \\
\text { no momento, no que está vivendo aqui e agora[...J" (sic). }\end{array}$ \\
& $\begin{array}{l}\text { "Melhorou bastante, assim que eu tenho animo, que eu sou mais alegre né de conviver com as } \\
\text { pessoas de idade também comigo, que apesar de tudo, eu acho a velhice assim muito triste, então, } \\
\text { eu não quero sentir essa tristeza né, não quero, porque eu vejo acabada assim as pessoas, não tem } \\
\text { vontade de nada né e isso me incomoda. Então aí eu disse, com o problema que eu tenho, eu tó } \\
\text { viva né, então achei bom vir para cá. E a gente ri, brinca e conversa ali né [...J" (sic). }\end{array}$ \\
\hline
\end{tabular}

Fonte: Elaborado pelo autora, 2019.

$\mathrm{Na}$ categoria benefícios nas relações interpessoais buscou-se analisar os benefícios que a prática do yoga em grupo pode proporcionar nas relações interpessoais dos seus praticantes (Quadro 06).

Quadro 06 - Benefícios nas Relações Interpessoais: 


\begin{tabular}{|c|c|}
\hline P 01 & $\begin{array}{l}\text { "Eu acho que, o mesmo que eu já falei antes, não dar tanta importância ao que não tem } \\
\text { importância, o yoga vai cada vez mais me melhorando. A querer ser boa também, a ser melhor do } \\
\text { que eu acho que eu sou, a não só boa, mas a não ser tão encrenqueira como eu era antes sabe. } \\
\text { Hoje também eu consigo chamar a minha mãe de mãezinha, chamo ela de minha criança[...]" } \\
\text { (sic). }\end{array}$ \\
\hline P 02 & $\begin{array}{l}\text { "De repente sim né, mas eu sou uma pessoa de fazer fácil amizade, de conversar sabe, sou bem } \\
\text { assim de fazer amizade. Eu já tinha uma facilidade antes, o yoga só trowo mais né, muito bom! } \\
\text { Tudo o que acrescenta é bom pra vida da gente [...]" (sic). }\end{array}$ \\
\hline P 03 & $\begin{array}{l}\text { "Tem coisas que eu não aceito, eu chego e dai a minha guria me sufoca muito, porque como parece } \\
\text { que ela só tem eu, ela só se apega em mim sabe, dai parece que ela tá sempre em cima, dai tem dia } \\
\text { que eu chego e falo "vocês deixam eu quieta [...]" (sic). }\end{array}$ \\
\hline P 04 & $\begin{array}{l}\text { "Melhorou muito, muito. Olha, melhorou no meu tratamento com o meu esposo sabe [...] Depois } \\
\text { do yoga eu melhorei mais ainda nesses pensamentos né, de não cutucar. Na familia também, depois } \\
\text { que eu vim aqui pro yoga eu comecei a pensar que a gente não pode ficar longe da familia, sem } \\
\text { ficar mais perto né, sem visitar, entende, passei a ligar mais pra minhas outras irmãs [...]" (sic). }\end{array}$ \\
\hline P 05 & $\begin{array}{l}\text { "Sim, é, eu acho que aqui, quando eu cheguei aqui eu cheguei mais retraida mas eu acho que } \\
\text { melhorou a interação em geral assim no grupo, com o grupo. Melhorou com o social assim, com } \\
\text { o grupo acho que eu tô mais sociável, porque eu sempre fui assim bastante antissocial. E hoje eu } \\
\text { acho que a meditação principalmente me ajudou bastante, assim porque essa prática de tu não } \\
\text { pensar, só alongar teu pensamento, só aumentar seu poder de concentração, eu acho que me deu } \\
\text { muita visão mais assim sabe, comecei a enxergar melhor a situação entendeu, a realidade, porque } \\
\text { quando tu não te concentra, que tu é muito ansiosa, tu perde muito da tua realidade atual né, então } \\
\text { dai tu não fica com muita visão da verdade das coisas Eu para mim a minha dificuldade com as } \\
\text { pessoas era essa, porque eu não ficava realmente ali, eu não observava realmente o que estava se } \\
\text { passando néf...]" (sic). }\end{array}$ \\
\hline P 06 & $\begin{array}{l}\text { "Eu gostei de conhecer mais pessoas né, que eu conheço [...] A orientadora é muito querida, as } \\
\text { mulherzinha tudo, nós temos até um grupo do yoga, estamos sempre se comunicando né. Agora } \\
\text { também tô me sentindo bem com ela (filha), nós estamos se dando bem. Quando ela vai lá em casa } \\
\text { me beija, a gente nunca se beijava. E foi depois que eu comecei aqui mesmo, eu notei esses dias } \\
\text { que ela tá mais amiga minha. Ela tá sempre mandando perguntar como é que eu tô, porque antes } \\
\text { eu era muito fechada com ela né. Ai eu acho que o yoga tá fazendo muito bem para mim, eu } \\
\text { pretendo continuar assim, enquanto tiver aqui pretendo contimuar....]" (sic). }\end{array}$ \\
\hline
\end{tabular}

Fonte: Elaborado pelo autora, 2019.

Na categoria regulação emocional após a prática do yoga buscou-se analisar mudanças a nível emocional que a prática do yoga pode proporcionar para seus praticantes (Quadro 07).

Quadro 07 - Regulação Emocional após a prática do yoga. 


\begin{tabular}{|c|c|}
\hline P 01 & $\begin{array}{l}\text { "É, antes era como se fosse uma continuidade, hoje eu percebo quando eu vou ficar alterada e } \\
\text { porque eu vou me alterar, mas eu fico quieta, claro, não é sempre né. Eu penso mais, eu fico mais } \\
\text { na minha. Hoje eu paro e penso antes de agir, as vezes eu até deixo pra lá[...]" (sic). }\end{array}$ \\
\hline P 02 & $\begin{array}{l}\text { "Sim, eu já estava aprendendo a me dominar antes né, com a terapia que a gente faz, mas o yoga, } \\
\text { tudo vem a acrescentar né[...]" (sic). }\end{array}$ \\
\hline $\mathrm{P} 03$ & $\begin{array}{l}\text { "É que eu tento mudar, né, eu tento ser diferente, eu sei que eu tenho os meus momentos, mas eu } \\
\text { não quero transmitir essa coisa que eu tenho. Mas em função assim do yoga, os meus sentimentos, } \\
\text { é que nem te falei não mudou nada. Eu tenho o meu momento aqui com o yoga, é sair do yoga a } \\
\text { coisa continua igual. Eu não demonstro assim muito para as pessoas, por isso que eu digo que eu } \\
\text { acho que eu precisaria de um psicólogo, porque assim em familia, em coisa assim eu não } \\
\text { demonstro o que eu sinto, entendeu?[...]" (sic). }\end{array}$ \\
\hline P 04 & $\begin{array}{l}\text { "Hoje eu não me tranco mais no quarto pra chorar, se eu choro, eu choro aqui entende, no yoga } \\
\text { e saio tranquila daqui, eu saio com a alma lavada. Hoje eu percebo emoções boas, porque eu } \\
\text { comecei a falar com as minhas irmãs. Agora eu escuto música, leio né que eu estou lendo e faço } \\
\text { palavras cruzadas, eu faço essas coisas assim né, eu mudei pra melhor. O yoga está me ajudando } \\
\text { muito, muito mesmo[...]" (sic). }\end{array}$ \\
\hline P05 & $\begin{array}{l}\text { "Bem mais, com isso que eu te falo, se tu não tá ansioso, se tu tá ali, se tu tá concentrado no } \\
\text { ambiente, no local, na pessoa e em ti mesmo, fica mais fácil de se perceber qualquer emoção tua, } \\
\text { tanto a do outro, como a tua. Um conhecimento interior né bem maior, aprender a lidar com as } \\
\text { emoções, porque dai tu te conhecendo, porque dai tu vai perceber quando alguma coisa se } \\
\text { manifesta em ti [...] tu vai te questionar, tu vai querer entender, tu vai querer ir a fundo naquele } \\
\text { sentimento né, o porquê, então eu acredito que melhorei bastante com isso. Então quer dizer que } \\
\text { ter emoção negativa não é ruim, tu tem é que saber porque eu tu tem, se ele é verdadeiro, do que } \\
\text { que ele vem, o que que causa né. Então hoje eu respiro fundo para depois agir. Claro, não é assim } \\
100 \%, \text { mas é bem mais, muito mais[...]" (sic). }\end{array}$ \\
\hline P 06 & $\begin{array}{l}\text { "Mas agora tô bem mesmo, tô me controlando mais, não tô mais com raiva. E como eu aprendi } \\
\text { que tu ficar com raiva teu corpo padece. Eu usei assim não pensar mais, fico pensando no grupo } \\
\text { aqui, que a orientadora também é muito boa, eu fico ah aqui a gente tem uma paz aqui né, então, } \\
\text { também tem uma paz dentro de casa. Então como que diz tu tem que evitar de procurar bagunça } \\
\text { néf...l" (sic). }\end{array}$ \\
\hline
\end{tabular}

Fonte: Elaborado pela autora, 2019.

\section{DISCUSSÃO}

A presente pesquisa teve como objetivos investigar se a prática do yoga influencia na qualidade de vida, no bem-estar e na regulação emocional do indivíduo, verificando sua contribuição para a saúde mental de praticantes, a importância psicossocial na vida do indivíduo, bem como, a influência da prática de yoga na promoção de saúde em pacientes de um CAPS-II do Litoral Norte do Rio Grande do Sul.

A análise das entrevistas obtidas nesta pesquisa foi feita a partir do método de Bardin (2011). Para isso, os conteúdos das entrevistas foram divididos em categorias de análise, destacando-se os dados mais relevantes coletados nas entrevistas. Assim juntamente com a fundamentação teórica, os dados obtidos na pesquisa corroboram para a melhor compreensão da influência da prática do yoga na qualidade de vida, promoção de bem-estar e na regulação emocional dos indivíduos pacientes de um CAPS-II do Litoral Norte do Rio Grande do Sul. 
A partir dos dados obtidos no questionário sociodemográfico, apresentados na tabela 01 , pode-se observar que a pesquisa foi realizada com seis mulheres, com idade entre 42 e 70 anos. A escolaridade varia entre ensino fundamental incompleto até ensino superior completo. Quatro participantes são casadas, moram com seus cônjuges e têm filhos, uma é divorciada e uma é viúva, sendo que ambas tem filhos e moram sozinhas. Das praticantes do yoga entrevistadas, cinco são aposentadas e uma está empregada, tendo renda entre um salário mínimo até dois salários mínimos e meio. Cinco das entrevistadas relataram realizar psicoterapia semanal atualmente, sendo que P05 iniciou há 2 meses e as demais estão a pelo menos 1 ano no processo terapêutico. Cinco disseram que fazem uso de psicofármacos com períodos variados de 6 meses até 10 anos de uso. Com relação ao tempo de prática do yoga, todas mencionaram estar na oficina há dois meses e nunca terem praticado a atividade antes. Quanto ao diagnóstico, P01, P02 e P04 foram diagnosticadas com depressão, P05 tem diagnóstico de depressão com sintomas psicóticos, P03 e P06 estão em atendimento para a saúde mental.

As entrevistadas são mulheres, fato este que se comprova no estudo de Mota, França e Freitas (2013), o qual estabelece sobre os benefícios para o público feminino, visto que o yoga traz alívio na tensão pré-menstrual, para as cólicas menstruais, assim como, é aconselhado para gestantes por proporcionar alívio das dores na coluna e equilíbrio físico.

Outro dado constatado através dos dados sócio demográficos foi que a idade das entrevistadas variou de 42 anos a 70 anos, o que pode ser explicado através do fato de que a maioria dos indivíduos buscam no yoga um método para o alívio de problemas físicos e a partir de 40 anos, geralmente, é a fase onde começam a aparecer dores musculares e na coluna, bem como, problemas cardiovasculares, entre outros (MOTA, FRANÇA \& FREITAS, 2013).

Quanto a escolaridade das entrevistadas, variou desde o ensino fundamental incompleto até o ensino superior completo. Nesse sentido, a literatura demonstra que a prática do yoga é buscada como uma estratégia de promoção da saúde e prevenção de doenças, assim como, com o objetivo de autoconhecimento e autocuidado, dados demonstram que o yoga é praticado na maioria dos centros urbanos do Brasil, por indivíduos de diferentes classes sociais, culturais e econômicas (MOTA, FRANÇA \& FREITAS, 2013).

Para muitas das entrevistadas, de acordo com a categoria descrita no quadro 01 "Motivo do Início da Prática do Yoga", o qual busca investigar o que as motivou, foi a busca 
por uma atividade que pudesse acrescentar positivamente no seu tratamento, bem como, que trouxesse maior qualidade de vida e bem-estar, conforme relatos: P01 "[...]para alongar a musculatura, relaxar, me ocupar[...] eu penso assim que se eu fizer o yoga que é alongamento assim, que são exercícios pra mente, pode me acalmar, me relaxar[...]" (sic); P02 “[...] sempre eu ouvi falar que era uma coisa boa, ai eu resolvi praticar[...]” (sic); P04 “[...] eu sentia dores no joelho né, no pescoço, nos braços, eu não podia dormir por cima do braço sabe e sempre me falavam né, que se eu fizesse alguma atividade assim, o yoga ia me passar [...]” (sic); P05 “[...] eu acho que eu senti necessidade de me comunicar em grupo, de ter uma vida social um pouquinho melhor assim porque eu estava me sentindo muito isolada, eu estava muito antissocial [...]” (sic); P06 “[...] a psicóloga disse para mim que eu tinha que fazer alguma coisa né, para me distrair, não ficar em casa muito [...]” (sic). Percebe-se através dos relatos que as integrantes do grupo buscavam melhorar alguns aspectos em sua vida, assim como, ficar mais calma, diminuir as dores corporais, melhorar as relações interpessoais, ocupar seu tempo, enfim, acreditaram que com a prática poderiam ter benefícios a nível emocional, físico e ainda, nas relações com o meio.

Neste sentido, a Organização Mundial da Saúde em 1986 já prevê que o indivíduo possa ter a capacidade para aumentar o controle sobre a sua saúde, assim como, poder melhorar essa. O conceito atual de saúde tem seu foco no coletivo, ou seja, preza por ações de promoção de saúde e ainda, tem como objetivos intervenções que promovam a qualidade de vida e o bem-estar dos indivíduos. Além disso, a promoção de saúde advém com a premissa de que os comportamentos do indivíduo causam impactos sobre sua saúde e que mudanças saudáveis podem melhorá-la, portanto, este conceito acaba por responsabilizar o indivíduo e a comunidade (SILVA \& HELENO, 2012).

Conforme os resultados das entrevistas, a participante P03 não buscou participar da oficina de yoga, pois, foi em busca de um atendimento psicológico, conforme relato: P03 “ $E$ que daí eu vim aqui, fiz o acolhimento e eles me chamaram pro yoga, embora eu tivesse pedido um psicólogo [...]” (sic), e embora ela não esteja tendo tantos benefícios a nível emocional e físico com a prática do yoga, esta vem sendo utilizada como uma estratégia para o alívio do estresse e ansiedade, assim como, para uma melhor interação social. Quando questionada se a prática do yoga trouxe benefícios para a sua vida, ela afirma: "[...] ah ela me traz assim mais tranquilidade, mais paz, parece que tu te tranquiliza, mas é que nem eu digo né, no momento que tu tá aqui a coisa assim vai que é uma maravilha né, tu te fecha assim 
pro mundo lá fora, tu fica aqui dentro [...] no momento que eu tô aqui tá bom, tá bem assim acolhedor [...]" (sic). P03 também afirma que “[...] se meu problema não fosse dentro de casa seria uma maravilha né, só o yoga, mas eu acho que eu precisaria de um acompanhamento psicológico também [...]” (sic), reforçando dessa forma que acredita que um atendimento psicológico, juntamente com a prática do yoga poderiam lhe trazer benefícios a nível emocional, ou seja, o yoga como prática complementar ao tratamento.

Através dos relatos obtidos na categoria "Dores e Doenças físicas", conforme quadro 02, a maioria das entrevistadas relataram sofrer com dores e/ou alguma doença física: P01 “[...] realmente eu tenho problemas na lombar e no ciático. Tenho também Psoríase há mais de dez anos e se acentuou há uns dois anos [...]” (sic); P02 “[...] eu tenho problema de hérnia de disco que de noite eu deitava parecia que eu tinha uma coisa que dava aqueles beliscões e puxava. Tenho pressão alta também [...]” (sic); P04 “[...] eu sentia dores no joelho né, no pescoço, nos braços, eu não podia dormir por cima do braço sabe [...]” (sic); P05 “[...] eu tenho asma né [...]” (sic); P06 “[...] eu sinto as dores né, dos parafusos que eu tenho na coluna. Tenho tendinite, diabetes e sou soropositivo [...]” (sic). Desta forma, as integrantes da oficina relataram que além do sofrimento emocional, também tem considerável sofrimento físico.

Atualmente, se sabe que a saúde mental depende da combinação de fatores biológicos, psicológicos e sociais, ou seja, a saúde pode ser vista através do modelo biopsicossocial, em que diversos fatores interagem entre si e determinam o processo de saúde e doença (ORGANIZAÇÃO MUNDIAL DA SAÚDE, 2002). Nesse sentido, uma alteração emocional negativa pode gerar uma alteração física desfavorável também, ou seja, pensamentos disfuncionais, geram emoções negativas e consequentemente afetam o corpo, acarretando em problemas na saúde física (GIMENEZ \& BERVIQUE, 2006).

A partir da categoria "Benefícios físicos oriundos da prática do yoga", no quadro 03, foi possível constatar que os participantes observam benefícios físicos após a prática, conforme relatos: P01 “[...] o yoga me estimula a ter que ir numa academia, por uma questão de saúde, eu tenho vontade e eu vejo necessidade fisica [...]” (sic); P02 “[...] eu tenho problema de hérnia de disco que de noite eu deitava parecia que eu tinha uma coisa que dava aqueles beliscões e puxava, desde que eu comecei a fazer o exercício de yoga [...] parece que eu corpo tá mais leve sabe? Não tô sentindo mais, tô adorando [...]” (sic); P04 “[...] não sinto mais dor assim pra dormir, nada, eu durmo e eu tenho bico de papagaio aqui no 
pescoço e eu não sinto mais dor, eu durmo bem melhor depois que eu estou fazendo, meu Deus olha pra mim foi um, bah [...]” (sic); P05 “[...] eu sinto que eu tô mais alongada, que eu tenho mais flexibilidade, que eu me sinto bem melhor assim com mais facilidade eu consigo acompanhar as posições, fazer os alongamentos, isso eu noto que melhorou bastante. A minha respiração também eu noto que melhorou, eu tenho asma né e tem me dado bem menos crise e tudo né [...]” (sic); P06 “Como eu tenho que caminhar, eu sinto as dores né, dos parafusos que eu tenho, mas ela desfaz devagarinho e eu senti que o corpo também relaxei bem. Depois que eu comecei o yoga eu notei que eu não tô mais sentindo dor, não me canso mais, então eu tô adorando vim [...]” (sic). Nesta categoria foi possível constatar diversos benefícios físicos oriundo da prática do yoga, fator este que gera maior bem-estar e melhor qualidade de vida aos praticantes.

Há algum tempo o Yoga vem se mostrando eficaz e eficiente na promoção de saúde dos indivíduos, além de ter baixos custos, também resulta em bons resultados em curto período de tempo, estudos comprovam que com três meses de prática, já se obtém importantes benefícios na saúde física e psíquica (PECANHA; CAMPANA 2010). O Yoga tem como objetivo desenvolver o potencial do corpo de forma integrada com a mente, desta forma, auxilia na diminuição das dificuldades físicas e emocionais (BERNARDI et al, 2013). Além disso, o Ministério da Saúde (2017) aponta que a prática do yoga diminui a frequência cardíaca e a pressão arterial, melhora a aptidão física, força e flexibilidade geral.

Relacionado a categoria "Benefícios psicológicos oriundos da prática do yoga", no quadro 04 , foi identificado que os entrevistados percebem mudanças psicológicas, conforme relatam: P01 "[...] quando a gente medita, a gente pode criar uma imagem melhor pra nós, então faz bem, porque pra mim é uma continuação da terapia [...]” (sic); P02 “[...] é muito bom pra cabeça da gente também né, os relaxamentos que a gente faz são maravilhosos [...]" (sic); P04 “[...] estou assim tranquila e pra dormir é um sonho porque a gente sai muito tranquila daqui, muito tranquila sabe, até meu esposo notou que eu estou bem mais calma [...]” (sic); P05 “[...] eu acredito que também no psicológico ajudou bastante a meditação que a gente faz ali, o relaxamento, me ajudou bastante, eu acredito que tenho conseguido controlar melhor a ansiedade, eu acho assim se eu tivesse um acompanhamento mais constante com a psiquiatra já tinha diminuído bastante essa medicação entendeu, porque tô me sentindo muito melhor [...]” (sic); P06 “Ah eu achei assim que eu relaxo, a hora que ela manda a gente deitar e relaxar. Também tô mais animada né. Eu adorei fazer, tomara que 
tenha sempre [...]" (sic). Através dos relatos é possível constatar que as integrantes da oficina de yoga obtiveram benefícios quanto aos aspectos psicológicos, assim como, observam benefícios na regulação emocional, aumento da sua autoestima e melhora nos relacionamentos interpessoais com a prática do yoga.

A prática do yoga como atividade física regular proporciona alterações positivas nas ondas de atividade cerebral, estando, portanto, relacionada a uma boa saúde mental, pois, traz benefícios como autoconfiança, autocontrole e redução dos sintomas depressivos (VORKAPIC \& RANGÉ, 2011). Além disso, a prática do yoga, segundo o Ministério da Saúde (2017), melhora a qualidade de vida, reduz o estresse, alivia a ansiedade, depressão e insônia.

Na categoria "Mudanças no Bem-Estar e na Qualidade de Vida Relacionadas à Prática do Yoga", apresentada no quadro 05, a qual busca identificar possíveis benefícios no bem-estar e na qualidade de vida das praticantes do yoga, é possível constatar um aumento da percepção de bem-estar, bem como, uma melhor qualidade de vida após a prática, conforme relatos: P1 “[...]a minha percepção de coisas boas aumentou[...]” (sic); P02 “[...] mudou praticamente tudo né [...] no bem-estar, no se sentir bem, bem mesmo [...] me sinto bem melhor para dormir principalmente [...] te relaxa, fisicamente a gente fica mais relaxada [...]” (sic); P04 “[...] eu me sinto bem mais tranquila, eu comecei a ler livros, eu comecei a tirar uma sonequinha meio-dia [...] é o relaxamento eu acho e os exercícios também fazem muito bem pra gente né [...]” (sic); P05 “[...] eu consigo dormir melhor [...] me sinto com mais disposição também [...] me sinto mais leve, mais relaxada [...] mais positiva [...] e eu acho que o benefício maior de tu não te sentir tão ansiosa, é que tu tem uma qualidade de vida bem melhor [...] tu consegue te concentrar melhor, nas coisas, no momento, no que está vivendo aqui e agora [...]" (sic); P06 “[...]eu tenho ânimo[...] sou mais alegre né de conviver com as pessoas de idade também comigo [...]” (sic). Através dos relatos obtidos nessa categoria pode-se perceber que as entrevistadas percebem benefícios relacionados ao bem-estar e a qualidade de vida após a prática do yoga, tais como, percepção positiva, melhora no sono, maior tranquilidade, disposição, relaxamento, leveza, concentração, ânimo e sensações de alegria. Estes resultados vão de encontro ao que Mota, França e Freitas (2013) destacam, ou seja, que a prática do yoga proporciona a promoção de bem-estar físico, emocional e social, ocasionando desta forma melhor qualidade de vida, por meio de sua prática psicofísica. 
$\mathrm{Na}$ categoria que busca investigar "Benefícios nas Relações Interpessoais", disposta no quadro 06, as entrevistadas relatam: P01: “[...] não dar tanta importância ao que não tem importância, o yoga vai cada vez mais me melhorando [...] a ser melhor do que eu acho que eu sou [...] a não ser tão encrenqueira como eu era antes sabe [...]” (sic); P02 “[...] eu já tinha uma facilidade antes, o yoga só trouxe mais né, muito bom [...]” (sic); P04 “[...] melhorou no meu tratamento com o meu esposo sabe [...] depois do yoga eu melhorei mais ainda nesses pensamentos né, de não cutucar [...] eu comecei a pensar que a gente não pode ficar longe da família [...] passei a ligar mais pra minhas outras irmãs [...]” (sic); P05 “[...] eu acho que melhorou a interação em geral assim no grupo [...] só aumentar seu poder de concentração [...] comecei a enxergar melhor a situação entendeu, a realidade [...]" (sic); P06 "Depois que eu comecei aqui mesmo, eu notei esses dias que ela (filha) tá mais amiga minha [...]" (sic). Por meio dos dados coletados observa-se que as participantes da pesquisa percebem uma melhora nas suas relações interpessoais, por meio de uma melhor percepção de si e do ambiente através da prática, bem como, através da aprendizagem de focar no presente. Vorkapic e Rangé (2011) confirmam estes resultados, pois, relatam que as técnicas e posturas utilizadas na prática do yoga possibilitam o desenvolvimento de uma maior percepção e compreensão de si, assim como, na qualidade das relações interpessoais.

$\mathrm{Na}$ categoria "Regulação Emocional após a prática do yoga", descrita no quadro 07, busca-se analisar mudanças a nível emocional que a prática do yoga pode proporcionar para seus praticantes, conforme relatos: P01 "[...] hoje eu percebo quando eu vou ficar alterada e porque eu vou me alterar [...] hoje eu paro e penso antes de agir [...]” (sic); P02 “[...] sim, eu já estava aprendendo a me dominar antes né, com a terapia que a gente faz, mas o yoga, tudo vem a acrescentar né [...]” (sic); P04 “[...] hoje eu percebo emoções boas [...]” (sic); P05 “Um conhecimento interior né bem maior, aprender a lidar com as emoções, porque daí tu te conhecendo [...] tu vê quando algum sentimento se manifesta em ti [...] tu vai te questionar [...] então eu acredito que melhorei bastante com isso...então hoje eu respiro fundo e faço uma respiração e tento analisar porque que eu tô com aquele sentimento assim para depois agir [...]” (sic); P06 “[...] tô me controlando mais, não tô mais com raiva [...]” (sic). É possível constatar, com os relatos das participantes, que elas estão com as emoções mais reguladas após a prática do yoga, pois, conseguem perceber melhor suas emoções, tanto positivas, quanto negativas, assim como, conseguem pensar mais antes de agir. 
Segundo Bernardi et al (2013) o yoga desenvolve os potenciais de mente e corpo de forma integrada, desta forma, auxilia na diminuição das dificuldades físicas e emocionais. Deste modo a prática do yoga propicia efeitos positivos, tais como, estado contínuo de energia, serenidade, autoconfiança, equilíbrio físico e emocional e, clareza emocional, portanto, diminui sintomas de ansiedade e estresse. Conforme referem os autores a prática do yoga busca fazer o indivíduo tomar contato com seu corpo e com seu interior, de modo a propiciar exercícios de condução mental, que possibilitam alterações na forma e no foco dos pensamentos e leva a transformações emocionais, bem como, no funcionamento dos sistemas orgânicos do indivíduo, assim, este se apropria do seu processo de cura e bem-estar.

\section{CONSIDERAÇÕES FINAIS}

O objetivo desta pesquisa foi identificar os benefícios do yoga como prática complementar ao tratamento, investigar se a prática do yoga influencia na qualidade de vida, na promoção de bem-estar e na regulação emocional de pacientes de um CAPS - II do Litoral Norte do Rio Grande do Sul.

Constatou-se que as participantes desta pesquisa apresentaram diversos benefícios a nível emocional, físico, psicológico e social com a prática do yoga. Quatro das seis participantes da pesquisa não apresentaram sintomas a nível psicossomático, de ansiedade, de insônia, de disfunção social e de depressão grave, segundo o Questionário de Saúde Geral de Goldberg (QSG-28). As participantes da pesquisa foram motivadas a iniciar a prática do yoga, pois, acreditavam que com a prática poderiam ter benefícios a nível emocional, físico e ainda, nas relações com o meio.

Após a prática do yoga as participantes desta pesquisa constataram diversos benefícios físicos, fator este que gera maior bem-estar e melhor qualidade de vida aos praticantes. Relataram também benefícios quanto aos aspectos psicológicos, assim como, observam benefícios na regulação emocional, aumento da sua autoestima e melhora nos relacionamentos interpessoais com a prática do yoga. Assim pode-se perceber que as entrevistadas percebem benefícios relacionados ao bem-estar e a qualidade de vida após a prática do yoga, tais como, percepção positiva, melhora no sono, maior tranquilidade, disposição, relaxamento, leveza, concentração, ânimo e sensações de alegria. Houve também melhora nas suas relações interpessoais, por meio de uma melhor percepção de si e do 
ambiente através da prática, bem como, através da aprendizagem de focar no presente. É possível constatar, com os relatos das participantes, que elas estão com as emoções mais reguladas após a prática do yoga, pois, conseguem perceber melhor suas emoções, tanto positivas, quanto negativas, assim como, conseguem pensar mais antes de agir.

Sugere-se como continuidade do estudo um maior número de participantes, incluindo mais homens, tendo em vista que nesta pesquisa não haviam indivíduos do gênero masculino, ou seja, não haviam homens participando da oficina de yoga no CAPS naquele momento. Com o aumento de indivíduos acometidos por transtornos mentais e com a implementação da prática do yoga na Política Nacional de Práticas Integrativas e Complementares (PNPIC), surge a necessidade de mais estudos na área para traçar estratégias de promoção de qualidade de vida e bem-estar na população em geral, bem como, em pacientes de Centros de Atenção Psicossociais.

\section{REFERÊNCIAS BIBLIOGRÁFICAS}

AGÊNCIA NACIONAL DE SAÚDE SUPLEMENTAR (Brasil). Diretrizes Assistenciais para a Saúde Mental na Saúde Suplementar. Rio de Janeiro: ANS, 2008. 75 p. Disponível em

$<$ http://www.ans.gov.br/images/stories/Plano_de_saude_e_Operadoras/Area_do_consumidor/ diretrizes_assistenciais.pdf $>$. Acesso em 05. Set. 2019.

ALBUQUERQUE, A. S.; TRÓCCOLI, B. T. (2004). Desenvolvimento de uma escala de bem-estar subjetivo. Psicologia: teoria e pesquisa, 20 (2), 153-164, 2004. Disponível em < http://www.scielo.br/pdf/ptp/v20n2/a08v20n2>. Acesso em 03. Set. 2019.

BARDIN, Laurence. Análise de Conteúdo: A Visão de Laurence Bardin. São Paulo: Edições 70, 2011.

BERNARDI, Marina Lima Daleprane et al. Efeitos da intervenção Hatha-Yoga nos níveis de estresse e ansiedade em mulheres mastectomizadas. Ciênc. saúde coletiva, Rio de Janeiro, v. 18, n. 12, p. 2013. 3621-3632, Disponível em < http://www.scielo.br/pdf/csc/v18n12/a18v18n12.pdf>. Acesso em 10 Mar. 2019. 
BUSS, P. M. Promoção da saúde e qualidade de vida. Ciência \& Saúde Coletiva, 5 (1), 163-177. 2000. Disponível em <http://www.scielo.br/pdf/csc/v5n1/7087.pdf>. Acesso em 03. Set. 2019.

FELICORI, Carolina Moreira. Estratégias de aprendizagem, compreensão leitora e regulação emocional: relações com o sucesso de estudantes no ingresso no Ensino Médio. 2017. 1 recurso online (136 p.). Dissertação (mestrado) - Universidade Estadual de Campinas, Faculdade de Educação, Campinas, SP. Disponível em < http://repositorio.unicamp.br/bitstream/REPOSIP/332425/1/Felicori_CarolinaMoreira_M.pdf >. Acesso em 10 set. 2019.

GAINO, Loraine Vivian et al. O conceito de saúde mental para profissionais de saúde: um estudo transversal e qualitativo*. SMAD, Rev. Eletrônica Saúde Mental Álcool Drog. (Ed. port.), Ribeirão Preto , v. 14, n. 2, p. 108-116, 2018 . Disponível em $<$ http://pepsic.bvsalud.org/scielo.php?script=sci_arttext\&pid=S1806-69762018000200007\&ln $\mathrm{g}=\mathrm{pt} \& \mathrm{nrm}=$ iso $>$. Acesso em 03 set. 2019.

GIL, A.C. Como elaborar projetos de pesquisa. 5a. Ed. São Paulo: Atlas, 2010.

GIMENEZ, Rosane Montefusco; BERVIQUE, Janete de Aguirre. Relação entre as Emoções e o Organismo como um Todo. Revista Científica Eletrônica de Psicologia. Ano IV, número 7, 2006. Periódicos Semestral. Garça/SP. Disponível em < http://faef.revista.inf.br/imagens_arquivos/arquivos_destaque/ri4hKpL8RT19wi8_2013-5-1015-32-13.pdf>. Acesso em 23 out. 2019.

GORESTEIN, C; WANG, YP; HUNGERBÜHLER, I (orgs). Instrumentos de avaliação em saúde mental. 2016. Artmed, Porto Alegre.

LEAHY, R. L.; TIRCH, D.; NAPOLITANO, L. A. Regulação emocional em psicoterapia: Um guia para o terapeuta cognitivo-comportamental. 2013. Porto Alegre: Artmed Editora. 
MEDEIROS, Alexsandro Melo. Práticas integrativas e complementares no SUS: os benefícios do Yoga e da Meditação para a saúde do corpo e da alma. Revista Eletrônica Correlatio, v. 16, n. 2017.20 Disponível em $<$ https://www.metodista.br/revistas/revistas-metodista/index.php/COR/article/view/8369/6145 >. Acesso em 05 set. 2019.

MINAYO, Maria Cecília de Souza; HARTZ, Zulmira Maria de Araújo; BUSS, Paulo Marchiori. Qualidade de vida e saúde: um debate necessário. Ciênc. saúde coletiva, Rio de Janeiro, v. 5, n. 1, p. 7-18, 2000. Disponível em $<$ http://www.scielo.br/scielo.php?script=sci_arttext\&pid=S1413-81232000000100002\&lng=e n\&nrm=iso $>$. Acesso em 06 Set. 2019.

MINISTÉRIO DA SAÚDE. Portaria n. 971, de 03 de maio de 2006. Aprova a Política Nacional de Práticas Integrativas e Complementares (PNPIC) no Sistema Único de Saúde. 2006. Disponível em:

$<$ http://bvsms.saude.gov.br/bvs/saudelegis/gm/2006/prt0971_03_05_2006.html $>$. Acesso em 05 set. 2019.

MINISTÉRIO DA SAÚDE. Portaria n. 849, de 27 de março de 2017. Inclui a Arteterapia, Ayurveda, Biodança, Dança Circular, Meditação, Musicoterapia, Naturopatia, Osteopatia, Quiropraxia, Reflexoterapia, Reiki, Shantala, Terapia Comunitária Integrati e Yoga à Política Nacional de Práticas Integrativas e Complementares. 2017. Disponível em:

$<$ http://www.lex.com.br/legis_27357131_PORTARIA_N_849_DE_27_DE_MARCO_DE_20 17.aspx>. Acesso em 05 set. 2019.

MOTA, E. O.; FRANÇA, R. R.; FREITAS, M.M. Efeitos Físicos e Psicológicos da Prática da Hatha Yoga em Adultos nas Instituições Privadas mm Salvador, Bahia. Scire Salutis, Aquidabã, v.3, n.2, 2013. Disponível em $<$ https://pdfs.semanticscholar.org/592d/dc4dbd927943431c121fcb442b1fbf2d0e79.pdf>. Acesso em 25 out. 2019. 
MURCHO, Nuno; PACHECO, Eusébio; JESUS, Saul Neves de. Transtornos mentais comuns nos Cuidados de Saúde Primários: Um estudo de revisão. Revista Portuguesa de Enfermagem de Saúde Mental, Porto, n. 15, p. 30-36, jun. 2016. Disponível em $<$ http://www.scielo.mec.pt/scielo.php?script=sci_arttext\&pid=S1647-21602016000100005\&1 ng=pt\&nrm=iso $>$. Acesso em 20 ago. 2019.

OLIVEIRA, J. A. Qualidade de vida e desempenho acadêmico de graduandos. Tese (Doutorado em Educação) - Faculdade de Educação: Universidade Estadual de Campinas. 2006. Disponível em http://repositorio.unicamp.br/bitstream/REPOSIP/252881/1/Oliveira_JoseAriCarlettide_D.pdf >. Acesso em 03. Set. 2019.

ORGANIZAÇÃO MUNDIAL DA SAÚDE. Carta de Ottawa para a promoção da saúde. 1986. Disponível em: <http://bvsms.saude.gov.br/bvs/publicacoes/carta_ottawa.pdf $>$. Acesso em 03. Set. 2019.

ORGANIZAÇÃO MUNDIAL DA SAÚDE. Relatório Mundial da Saúde: saúde mental: nova concepção, nova esperança. Lisboa: Ministério da Saúde/Direcção Geral da Saúde. 2002. Disponível em $<$ http://psiquiatriabh.com.br/wp/wp-content/uploads/2015/01/Relatorio-OMS-da-saude-menta 1-no-mundo-2001.pdf>. Acesso em 03 set. 2019.

PASSARELI, P. M.; SILVA, J. A. Psicologia positiva e o estudo do bem-estar subjetivo. Estudos de Psicologia, 24 (4), 513- 517, 2007. Disponível em $<$ http://www.scielo.br/pdf/estpsi/v24n4/v24n4a10.pdf>. Acesso em 03. Set. 2019.

PECANHA, Doris Lieth; CAMPANA, Daniel Perdigão. Avaliação quali-quantitativa de intervenção com yoga na promoção da qualidade de vida em uma universidade. Bol. - Acad. Paul. Psicol., São Paulo, v. 30, n. 1, p. 199-218, jun. 2010 . Disponível em $<$ http://pepsic.bvsalud.org/scielo.php?script=sci_arttext\&pid=S1415-711X2010000100014\&1 ng=pt\&nrm=iso $>$. Acesso em 27 abr. 2019. 
RIBEIRO, J. L.; GALINHA, I. História e evolução do conceito de bem-estar subjetivo. Psicologia, Saúde \& Doenças, 6 (2), 203-214. 2005. Disponível em: $<$ http://www.redalyc.org/articulo.oa?id=36260208>. Acesso em 03. Set. 2019.

SENICATO, Caroline; AZEVEDO, Renata Cruz Soares de; BARROS, Marilisa Berti de Azevedo. Transtorno mental comum em mulheres adultas: identificando os segmentos mais vulneráveis. Ciênc. saúde coletiva, Rio de Janeiro, v. 23, n. 8, p. 2543-2554, ago. 2018. Disponível em $<$ http://www.scielo.br/scielo.php?script=sci_arttext\&pid=S1413-81232018000802543\&lng=p t\&nrm=iso $>$. Acesso em 25 ago 2019.

SILVA, Eliana; FREIRE, Teresa. Regulação emocional em adolescentes e seus pais: Da psicopatologia ao funcionamento ótimo. Aná. Psicológica, Lisboa, v. 32, n. 2, p. 187-198, jun. 2014.

Disponível

em $<$ http://www.scielo.mec.pt/scielo.php?script=sci_arttext\&pid=S0870-82312014000200005\&1 ng=pt\&nrm=iso $>$. Acesso em 11 set. 2019.

SILVA, Érika Correia; HELENO, Maria Geralda Viana. Qualidade de Vida e Bem-Estar Subjetivo de Estudantes Universitários. Revista Psicologia e Saúde, [S.1.], jul. 2012. ISSN 2177-093X. Disponível em:

$<$ http://www.gpec.ucdb.br/pssa/index.php/pssa/article/view/126>. Acesso em: 03 set.

VORKAPIC, C. F.; RANGÉ, B. Os benefícios do yoga nos transtornos de ansiedade. Revista Brasileira de Terapias Cognitivas, v.7, n.1, p.50-54, 2011. Disponível em: $<$ http://pepsic.bvsalud.org/scielo.php?script=sci_arttext\&pid=S1808-56872011000100009\&ln $\mathrm{g}=\mathrm{pt \& nrm}=$ iso $>$. Acesso em 25 out. 2019. 